\title{
APPLICATION OF GA3 AND HARVEST SEASON INTERFERE IN PINEAPPLE YIELD AND FRUIT QUALITY
}

\author{
GARCIA, Rogério Braga Maciel ${ }^{1}$ \\ SIEBENEICHLER, Susana Cristine ${ }^{2}$ \\ SANTOS, Elonha Rodrigues dos \\ ADORIAN, Gentil Cavalheiro \\ LORENÇONI, Rogério \\ SOUZA, Clóvis Maurílio de \\ VELOSO, Ronice Alves \\ OLIVEIRA, Magno de
}

SUMMARY: This study aimed to evaluate the effect of GA3 (gibberellic acid) application on growing pineapple 'Pérola' fruits, and also the harvest season on yield, and fruit quality. The experimental design used was randomized blocks in $5 \times 2$ factorial design, being the first factor the application of GA3, and the second the harvest season, totaling in 10 treatments with four replicates, in split-plot plots. The treatments tested were: 1) GA3 application after the appearance of the first flower open on the inflorescence; 2) application of GA3 after the closing of the flowers in the inflorescence; 3) application of GA3 45 days before the first harvest; 4) two applications of GA3: one after the closing of flowers and another 45 days before the first fruits harvest; and 5) without application of GA3. Two harvest seasons were evaluated: 150 and 180 days after the floral induction. The phytoregulator Pro-Gibb® in a concentration of $200 \mathrm{mg} \mathrm{L}^{-1}$ of GA3 was adopted. The variables assessments were: fruit length with crown and without, crown length and mass, crownless fruit mass, average fruit mass and yield, titratable acidity, total soluble solids, and $\mathrm{pH}$ of the juice. The harvest of pineapple fruits held 180 days after floral induction, combined with an application of GA3 45 days before the harvest, provided greater yield while maintaining and improving the quality of pineapple 'Pérola' fruits. The use of GA3 did not influence the pineapple yield when the harvest is performed early, i.e. 150 days after flower induction.

Keywords: Ananas comosus var. Comosus. Growth regulator. Gibberellic acid. Cultivar Pérola

RESUMO: Este trabalho objetiva avaliar o efeito da aplicação de $\mathrm{GA}_{3}$ (ácido giberélico) no fruto de abacaxi 'Pérola' em desenvolvimento e a época de colheita na produtividade e qualidade do fruto. O delineamento experimental foi o de blocos casualizados em esquema fatorial $5 \times 2$, sendo o primeiro fator época de aplicação do $\mathrm{GA}_{3}$ e o segundo a época de colheita, totalizando 10 tratamentos com quatro repetições, com parcela subdividida. Os tratamentos testados foram: 1) aplicação do $\mathrm{GA}_{3}$ após o aparecimento da primeira flor aberta na inflorescência; 2) aplicação do $\mathrm{GA}_{3}$ após o fechamento das flores na inflorescência; 3) aplicação do $\mathrm{GA}_{3}$ aos 45 dias antes de realizar a primeira colheita; 4) duas aplicações do $\mathrm{GA}_{3}$ : uma após o fechamento das flores e outra aos 45 dias antes da primeira colheita dos frutos; e 5) sem aplicação de $\mathrm{GA}_{3}$. E duas épocas de colheita: 150 e 180 dias após a indução floral. Utilizou o fitorregulador Pro-Gibb® como concentração de $200 \mathrm{mg} \mathrm{L}^{-1}$ de $\mathrm{GA}_{3}$. As variáveis avaliadas foram: comprimento do fruto com e sem coroa, comprimento e massa da coroa, massa do fruto sem coroa, massa média do fruto e produtividade, acidez titulável, teor de sólidos solúveis totais e $\mathrm{pH}$ do suco. A colheita dos frutos de abacaxi realizada, aos 180 dias após a indução floral, com aplicação do $\mathrm{GA}_{3}$ aos 45 dias antes da colheita, proporcionou maior produtividade mantendo e melhorando a qualidade dos frutos de abacaxi 'Pérola'. $\mathrm{O}$ uso do GA $\mathrm{A}_{3}$ não influência na produtividade do abacaxi quando a colheita é realizada precoce, ou seja, aos 150 dias após a indução floral.

Palavras-chave: Ananas comosus var. Comosus. Regulador de crescimento. Ácido giberélico. Cultivar Pérola

\footnotetext{
${ }^{1}$ Maciel \& Garcia Ltda (Agroplante)

${ }^{2}$ Universidade Federal do Tocantins- Campus de Gurupi
} 


\section{INTRODUCTION}

Pineapple (Ananas comosus) is a monocot of the Bromeliaceae, being the only edible fruit of this family. The fruit is one of the most important marketed worldwide, representing $20 \%$ of tropical fruit production in the world. About $70 \%$ of the pineapple is consumed fresh; however, the juice has been gaining popularity on export (SAHOO et al., 2015).

In Brazil, pineapple is a high profitability crop, being the fourth fruit in production, with a production of 2,253,897 tonnes in 2017 (FAO, 2018). The main producing States are Pará, Paraíba, and Minas Gerais, with percentual participation compared to national production of 21.1, 16.5 and $14.9 \%$, respectively; the State of Tocantins accounts for 3.2\% of the cultivated area (4,652 ha), reaching yields of of 20,231 fruit ha ${ }^{-1}$ (IBGE, 2016). Much of this result can be attributed to soil and climate conditions favorable to the crop development in the State.

For marketing, the pineapple fruits are classified by the size, (CQH/CEAGESP, 2003), being considered six classes: fruits up to 2,400 g are considered large and fruit weighing between 900 to $1200 \mathrm{~g}$ are considered small. In Tocantins, only three classes are considered: small, medium and large, to fruit weighing between 900 and 1299, between 1300 and 1599 and above $1600 \mathrm{~g}$, respectively. The production of small and medium-sized fruits represents great economic loss, as the cost of production is the same, regardless the size. According to Bengozi et al. (2007), the variations of average fruit weight is directly related to the production technology adopted by each grower.

Gibberellic acid promotes cell division and elongation, acting in various physiological processes at different phenological stages of the plant. This hormone can influence the growth, floral initiation and fruiting of several plants, including the pineapple, in which the use of gibberellic acid resulted in an increase in fruits weight (TAIZ; ZEIGER, 2009).

The use of gibberellic acid on fruit production has become a viable alternative and has been used in several crops, such as grapes (VIEIRA et al., 2008), Citrus reticulata blanco (MODESTO et al., 2006; MACDONALD et al., 2010), Citrus limon (SUKANYA, et al., 2017), peach (PANDE et al., 2011; GAMBO et al., 2016), Strawberry (SHARMA et al., 2009) and pineapple (LI et al. 2011). However, in Brazil, studies using gibberellic acid on pineapple to assess whether there is an increase in production and fruit quality are still incipient.

In light of this, the aim was to evaluate the effect of GA3 (gibberellic acid) application at two stages of pineapple fruit development, as well as the harvest season on yield and fruit quality, in Tocantins, Brazil.

\section{MATERIAL E METHOD}

The experiment was conducted at Brasília farm, in Alvorada, TO, Brazil, located at $12^{\circ} 28^{\prime} 48^{\prime \prime S}$ and $49^{\circ} 07^{\prime} 29^{\prime \prime} \mathrm{W}$, at 289 meters of altitude, from 2007 to 2009. The climate according to Köppen (1948) is classified as B1WA'a', humid with moderate water deficiency. The average annual temperature and precipitation are $26^{\circ} \mathrm{C}$ and $1700 \mathrm{~mm}$, respectively.

The experiment was set out in October 2007, after the beginning of the rainy season, under conventional tillage system, after plowing and harrowing. The experimental design used was randomized blocks in 5 x 2 factorial scheme, being the first factor the GA3 application, and the second the pineapple harvest season, totaling in 10 treatments with four replicates.

The treatments tested in times of GA3 application were: 1) GA3 application after the appearance of the first flower open on the inflorescence; 2) application of GA3 after the closing of the flowers in the 
inflorescence; 3) application of GA3 45 days before the first harvest; 4) two applications of GA3: one after the closing of flowers and another 45 days before the first fruits harvest; and 5) without application of GA3 (control). Two harvest seasons were also evaluated: 1) 150 days after the floral induction (March 2009); 2) 180 days after floral induction (April 2009).

The cultivar 'Pérola' was used. The phytoregulator Pro-Gibb® (GA3) at a concentration of 200 $m g L^{-1}$ of GA3 was adopted.

The pineapple was planted in double rows with spacing of $1.30 \times 0.50 \times 0.40 \mathrm{~m}$, corresponding to 26,500 plants ha ${ }^{-1}$. Each plot was composed of 180 plants, occupying an area of $43.2 \mathrm{~m}^{2}$, and each block with $216 \mathrm{~m}^{2}$ with 900 plants, being the total area of the experiment of $864 \mathrm{~m}^{2}$ (3600 plants). The two central rows were considered as useful areas, eliminating two plants of each row at the ends. The experiment was installed in split-plot desing, allocating the GA3 application in the main plot, and the harvest seasons in the split-plot.

The fertilization was conducted as recommended for the crop, according to soil analysis.

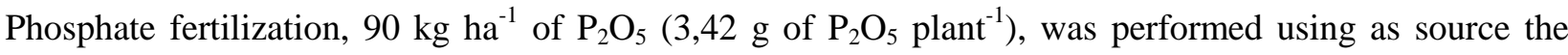
single superphosphate. On the same occasion, $3 \mathrm{~g}_{\text {plant }}{ }^{-1}$ of Fritas-BR-12 was applied as micronutrients source. The topdressing was performed with three applications of $15 \mathrm{~g}$ of N20-P00-K20, at 60, 90, and 150 days after planting.

The crop was kept free of weed throughout the cycle by hoeing, and without irrigation in the dry season. At 12 months, after the seedlings planting, the floral induction was performed by adding $1 \mathrm{~g}$ calcium carbide stone in leaf rosette.

For production assessments, 20 fruits of each plot useful area were collected, for each harvest season, totalling 80 fruits per season. The variables of physical assessments were: fruit length with crown (FLWC), in $\mathrm{cm}$; b) crownless fruit length (CFL), in $\mathrm{cm}$; c) crown length $(\mathrm{CL})$, in $\mathrm{cm}$; d) crown mass $(\mathrm{CM})$, in $\mathrm{g}$; e) crownless fruit mass (CFM), in $\mathrm{g}$; $\mathrm{f}$ ) average fruit mass (AFM), in g; and (g) yield, in $\mathrm{kg} \mathrm{ha}$ ${ }^{1}$ (considering the fruit mass in a $\mathrm{m}^{2}$ ).

From each plot, four fruits were selected to perform the chemical analysis in Food Processing Laboratory of the Federal University of Tocantins - Campus Gurup. After obtaining the fruit juice, the following variables were assessed: a) titratable acidity (TA), methodology of titration with $0, \mathrm{~N}$ sodium hydroxide; b) total soluble solids content by refractometry ( $\left.{ }^{\circ} \mathrm{BRIX}\right)$; and c) $\mathrm{pH}$ of the juice by Micronal pH meter.

Data were subjected to analysis of variance using the F test, and the comparison of means was performed by Tukey test at $5 \%$ of probability.

\section{RESULT}

\section{Physical analysis of the fruits}

The timing of GA3applications did not affect the FLWC and the CL of pineapple (Table 1). A significant difference was observed for these variables only for the harvest seasons, whereas harvesting at 180 DAFI (days after floral induction) was superior to 150 DAIF. 
Table 1: Pineapple fruit length with crown (FLWC), crownless fruit length (CFL), crown length (CL) in function of GA3 application and two harvest seasons, 150 and 180 days after floral induction (DAFI) in Tocantins, Brazil.

\begin{tabular}{llllllc}
\hline & \multicolumn{2}{c}{ FLWC $(\mathbf{c m})$} & \multicolumn{2}{c}{ CFL $(\mathbf{c m})$} & \multicolumn{2}{c}{ CL $(\mathbf{c m})$} \\
\cline { 2 - 6 } \multicolumn{1}{c}{ GA3 application } & $\mathbf{1 5 0}$ DAFI & $\mathbf{1 8 0}$ DAFI & $\mathbf{1 5 0}$ DAFI & $\mathbf{1 8 0}$ DAFI & $\mathbf{1 5 0}$ & $\mathbf{1 8 0}$ \\
& & & & & DAFI & DAFI \\
\hline After the first open flower & $39.3 \mathrm{Ba}$ & $42.5 \mathrm{Aa}$ & $15.8 \mathrm{Aa}$ & $15.3 \mathrm{Aa}$ & $23.5 \mathrm{Ba}$ & $27.2 \mathrm{Aa}$ \\
At the end of flowering & $38.4 \mathrm{Ba}$ & $41.5 \mathrm{Aa}$ & $15.3 \mathrm{Aa}$ & $15.7 \mathrm{Aa}$ & $23.1 \mathrm{Ba}$ & $25.7 \mathrm{Aa}$ \\
45 days before harvest (DBH) & $39.4 \mathrm{Ba}$ & $42.6 \mathrm{Aa}$ & $16.4 \mathrm{Aa}$ & $16.2 \mathrm{Aa}$ & $23.1 \mathrm{Ba}$ & $26.4 \mathrm{Aa}$ \\
End of flowering and $45 \mathrm{DBH}$ & $38.3 \mathrm{Ba}$ & $41.6 \mathrm{Aa}$ & $14.8 \mathrm{Aa}$ & $14.7 \mathrm{Aa}$ & $23.5 \mathrm{Ba}$ & $26.9 \mathrm{Aa}$ \\
Without GA application & $38.8 \mathrm{Ba}$ & $42.0 \mathrm{Aa}$ & $15.1 \mathrm{Aa}$ & $15.2 \mathrm{Aa}$ & $23.6 \mathrm{Ba}$ & $26.8 \mathrm{Aa}$ \\
(Control) & & & & & & \\
\hline CV\% & 1.80 & & 4.37 & & 3.98 \\
\hline
\end{tabular}

The averages followed the same capital letter in the row, and by the same lowercase letter in the column, did not differ by the Tukey test at $5 \%$ probability.

* Floral induction occurred 12 months after planting, using $1 \mathrm{~g}$ of calcium carbide per plant.

Regarding CFL, there was no significant difference between the times of GA3 application or between the harvest season (Table 1). This demonstrates that, in the later harvest, there is a slight increase of the crown, an average of $3.24 \mathrm{~cm}$, not influencing in fruit marketing.

Comparing the harvest seasons for $\mathrm{CM}$, a significant increase was observed in treatments in which was applied GA3 at the end of flowering and 45 days before the harvest, and for the control at the second harvest season (Table 2).

Table 2: Crown mass (CM), crownless fruit mass (CFM) in function of GA3 application and two harvest seasons, 150 and 180 days after floral induction (DAFI), in Tocantins, Brazil

\begin{tabular}{lcccc}
\hline \multirow{2}{*}{\multicolumn{1}{c}{ GA3 application }} & \multicolumn{2}{c}{ CM (g) } & \multicolumn{2}{c}{ CFM (g) } \\
\cline { 2 - 5 } \multicolumn{1}{c}{ 150 DAFI } & 180 DAFI & 150 DAFI & 180 DAFI \\
\hline After the first open flower & $210 \mathrm{Aa}$ & $212 \mathrm{Ab}$ & $1289 \mathrm{Aa}$ & $1302 \mathrm{Aa}$ \\
At the end of flowering & $200 \mathrm{Aa}$ & $212 \mathrm{Ab}$ & $1288 \mathrm{Aa}$ & $1255 \mathrm{Aa}$ \\
45 days before harvest (DBH) & $191 \mathrm{Ba}$ & $276 \mathrm{Aab}$ & $1362 \mathrm{Aa}$ & $1391 \mathrm{Aa}$ \\
End of flowering and 45 DBH & $199 \mathrm{Ba}$ & $312 \mathrm{Aa}$ & $1256 \mathrm{Aa}$ & $1245 \mathrm{Aa}$ \\
Without GA $\mathrm{Aapplication}_{3}$ (Control) & $179 \mathrm{Ba}$ & $269 \mathrm{Aab}$ & $1234 \mathrm{Aa}$ & $1151 \mathrm{Aa}$ \\
\hline CV\% & \multicolumn{2}{c}{7.62} & \multicolumn{2}{c}{7.24} \\
\hline
\end{tabular}

The averages followed the same capital letter in the row, and by the same lowercase letter in the column, did not differ by the Tukey test at $5 \%$ probability.

* Floral induction occurred 12 months after planting, using $1 \mathrm{~g}$ of calcium carbide per plant.

Comparing GA3 application modalities in pineapple fruit as to the $\mathrm{CM}$, there was a significant increase in the treatment with two applications, being one at the end of the flowering and the other 45 days after flowering, in relation to the treatments that received the GA3 application after first flower opened and at the end of flowering (Table 2).

The GA3 application before the opening of the flower does neither interfere the CM, nor the CL (Tables 1 and 2). Possibly, this effect could be justified by the crown size in the stage of fruit development when the GA3 was applied, in which the crown was still developing.

The harvest season and times of GA3 application did not affect the CFM (Table 2).

There was a significant difference for AFM and yield between the harvest season for fruits that GA3 application 45 days before the harvest, whereas the fruits harvested at 180 DAFI were superior to the ones harvested 150 DAFI (Table 3). 
Table 3: Average fruit mass (AFM) and pineapple fruit yield in function of GA3 application and two harvest seasons of harvest, 150 and 180 days after floral induction (DAFI), in Tocantins, Brazil.

\begin{tabular}{lcccc}
\hline \multirow{2}{*}{ GA3 application } & \multicolumn{2}{c}{ AFM $(\mathbf{g})$} & \multicolumn{2}{c}{ Yield (t ha $\left.\mathbf{~}^{-1}\right)$} \\
\cline { 2 - 5 } & $\mathbf{1 5 0}$ DAFI & 180 DAFI & 150 DAFI & 180 DAFI \\
\hline After the first open flower & $1491 \mathrm{Aa}$ & $1555 \mathrm{Aab}$ & $35.0 \mathrm{Aa}$ & $37.9 \mathrm{Aab}$ \\
At the end of flowering & $1473 \mathrm{Aa}$ & $1600 \mathrm{Aab}$ & $36.0 \mathrm{Aa}$ & $38.7 \mathrm{Aab}$ \\
45 days before harvest (DBH) & $1478 \mathrm{Ba}$ & $1699 \mathrm{Aa}$ & $35.4 \mathrm{Ba}$ & $40.4 \mathrm{Aa}$ \\
End of flowering and 45 DBH & $1423 \mathrm{Aa}$ & $1545 \mathrm{Aab}$ & $34.0 \mathrm{Aa}$ & $37.0 \mathrm{Aab}$ \\
Without GA application & $1460 \mathrm{Aa}$ & $1433 \mathrm{Ab}$ & $34.6 \mathrm{Aa}$ & $34.0 \mathrm{Ab}$ \\
(Control) & & & & 6.94 \\
\hline $\mathrm{CV}(\%)$ & & 6.53 & & \\
\hline
\end{tabular}

The averages followed the same capital letter in the row, and by the same lowercase letter in the column, did not differ by the Tukey test at $5 \%$ probability.

* Floral induction occurred 12 months after planting, using $1 \mathrm{~g}$ of calcium carbide per plant.

There was no difference for AFM and yield in harvest performed at 150 DAIF. However, in the second harvest (180 DAIF), the GA3 application 45 days before the harvest showed the highest increase in these two variables, compared with the control (no GA3 application).

The application of GA3 45 days before the harvest increased the yield in $5 \mathrm{t} \mathrm{ha}^{-1}$ when compared the harvest performed at 180 DAFI to 150 DAFI (Table 3). These results demonstrate that the harvest at the right time is of utmost importance to maximize profits from farming.

\section{Chemical analysis of fruit}

For the harvest at $150 \mathrm{DAFI}$, no influence of GA3 in the fruit chemical variables (SS, TA, and $\mathrm{pH}$ ) was observed (Table 4). For the fruits harvested at 180 DAFI, a significant difference for the use of the GA3 was only verified for TA. Lower TA values were observed when GA3 was applied after the first flower opened and 45 days before the harvest. The plants that received two GA3 applications, one after the closing of flowers and another 45 days before the first harvest, presented fruits with higher TA, averaging 0.48 .

Table 4: Chemical analysis of pineapple fruits: soluble solids (SS), titratable acidity (TA) and $\mathrm{pH}$, in function of gibberelic acid (GA3) application and two harvest seasons, 150 and 180 days after floral induction (DAFI), in Tocantins, Brazil.

\begin{tabular}{|c|c|c|c|c|c|c|}
\hline \multirow{2}{*}{ GA3 application } & \multicolumn{2}{|c|}{ SS $\left({ }^{\circ}\right.$ Brix $)$} & \multicolumn{2}{|c|}{ AT (\%) } & \multicolumn{2}{|c|}{ pH } \\
\hline & 150 DAFI & 180 DAFI & 150 DAFI & 180 DAFI & 150 DAFI & 180 DAFI \\
\hline After the first open flower & $13.8 \mathrm{Ba}$ & $15.2 \mathrm{Aa}$ & $0.57 \mathrm{Aa}$ & $0.41 \mathrm{Bb}$ & $3.32 \mathrm{Ba}$ & $3.60 \mathrm{Aab}$ \\
\hline At the end of flowering & 13.9 Ba & 15.6 Aa & $0.53 \mathrm{Aa}$ & $0.46 \mathrm{Bab}$ & $\mathrm{Ba}$ & Aab \\
\hline 45 days before harvest (DBH) & $13.8 \mathrm{Ba}$ & 15.1 Aa & $0.54 \mathrm{Aa}$ & $0.40 \mathrm{Bb}$ & $\mathrm{Ba}$ & $3.83 \mathrm{Aa}$ \\
\hline End of flowering and $45 \mathrm{DBH}$ & $13.9 \mathrm{Ba}$ & $15.4 \mathrm{~A}$ & $0.51 \mathrm{Aa}$ & $0.48 \mathrm{Aa}$ & $3.33 \mathrm{Ba}$ & $3.62 \mathrm{Aab}$ \\
\hline $\begin{array}{l}\text { Without } \mathrm{GA}_{3} \quad \text { application } \\
\text { (Control) }\end{array}$ & $13.5 \mathrm{Ba}$ & $15.5 \mathrm{Aa}$ & $0.52 \mathrm{Aa}$ & $0.45 \mathrm{Bab}$ & $3.30 \mathrm{Ba}$ & $3.57 \mathrm{Ab}$ \\
\hline $\mathrm{CV} \%$ & 3 & & 5.7 & & 2,7 & 71 \\
\hline \multicolumn{7}{|c|}{$\begin{array}{l}\text { The averages followed the same capital letter in the row, and by the same lowercase letter in the column, did not } \\
\text { differ by the Tukey test at } 5 \% \text { probability. } \\
* \text { Floral induction occurred } 12 \text { months after planting, using } 1 \mathrm{~g} \text { of calcium carbide per plant. }\end{array}$} \\
\hline $\begin{array}{l}\text { The three chemical char } \\
\text { harvest season. In general, for } \\
\text { harvested at } 180 \text { DAFI (Table } 4\end{array}$ & $\begin{array}{l}\text { ristics e } \\
\text { y treatm }\end{array}$ & $\begin{array}{l}\text { ated (SS, } \\
\text { with GA? }\end{array}$ & $\begin{array}{l}\mathrm{A} \text { and } \mathrm{pH}) \mathrm{w} \\
\mathrm{S} \text { and } \mathrm{pH}\end{array}$ & $\begin{array}{l}\text { re sign } \\
\text { creasec }\end{array}$ & & sed when \\
\hline
\end{tabular}

Nucleus,v.16,n.2,out.2019 
The reduction in TA in fruits harvested at 180DAFI is possibly due to the acidity dilution due higher water accumulation in the fruit during maturation. Despite this dilution effect, TA levels remained above the number considered ideal for fresh 'Pérola' pineapple consumption, of $0.3 \%$. However, for plants that received two GA3 applications, when harvested at 180 days, showed a higher TA, differing statistically from plants that received the GA3 application after the appearance of the first flower open on the inflorescence and application of GA3 45 days before harvest.

The application of GA3 45 days before the harvest increased the fruit $\mathrm{pH}$, which differed statistically from the fruits that did not receive GA3 application (control).

The use of GA3 on pineapple croppinf can be considered a viable technique because it increases the yield without interfering with the fruit quality.

\section{DISCUSSION}

Pereira et al. (2009) evaluated fruits commercialized by a cooperative located in a producing region in Tocantins. The crown length of the fruits harvested in this experiment was greater than those evaluated by the aforementioned authors, especially in the second harvest, demonstrating a negative effect of increasing the fruit cycle in its visual quality.

An increase in fruit length was observed in pineapple 'Comte de Paris', using $50 \mathrm{mg} \mathrm{L}^{-1}$ of GA3 (LI et al, 2011). However, these authors suggest that the application of GA3 has a greater effect on fruit diameter than on its length, perhaps this is the reason for not observing influence of GA3 application on fruit length.

Li et al. (2011) also observed that the GA3 application up to 15 days after flowering increased the crown mass, a period close to that applied in this study.

The crown mass in the first harvest is within the range found by Pereira et al. (2009), and those of the second harvest are above these, except for the fruits that received the GA3 application after the first flower opened. The crownless fruit mass in both harvests is within the range of variation reported by Pereira et al. (2009).

According to Pires e Botelho (2002), GA3 generate $\alpha$-amylases that hydrolyze the starch, increasing the production of soluble sugars, which increases the osmotic pressure of the cellular juice, allowing the water to enter the cells, promoting cell expansion. Consequently, the inflow of water contributes to the increase of the cell wall elasticity and the elongation of the cell, which promotes the increase in its mass. This fact may have contributed to the increase in fruit length and mass observed in the present study.

Sharma et al. (2011) reported that GA3 possibly contributed to the elongation of strawberry fruit cells. In addition, these authors also discussed the interference of this hormone in the metabolism of auxin that may also have indirectly contributed to the elongation of the cells, and thus the increase in fruit size.

When using $50 \mathrm{mg} \mathrm{L}^{-1}$ of GA3 in an application up to 15 days after flowering, Li et al. (2011) observed a significant increase in fresh fruit mass. Vieira et al. (2008) concluded that GA3 applications in grape berries induced an increase in the number of cells, but reduced their size, that is, the reduction of cell size was compensated by the larger number of cells per $\mathrm{mm}^{-2}$, being the cell division more intense with applications of GA3 at $49 \mathrm{mg} \mathrm{L}^{-1}$.

As GA3 is a plant growth hormone that acts on growth points, when in contact with the fruit crown, it could cause its growth to be excessive, reducing the physical quality of the fruit, however, this was not observed in this study. Commercially, a large crown disqualifies the fruit, and its transportation in marketing boxes becomes unfeasible. 
Regarding the physical-chemical quality survey of the pineapple fruits marketed in Tocantins, performed by Pereira et al. (2009), the mass of fruits, harvested in the two seasons and independent of hormone, are within the acceptable range for the State.

Li et al. (2011) also did not observe effect of the application of $50 \mathrm{mg} \mathrm{L}^{-1}$ of GA3 on pineapple fruit quality, except for vitamin $\mathrm{C}$ that increased with the application of this dose. Modesto et al. (2006) observed that the results of soluble solids and titratable acidity in 'Poncã' tangerine juice were not influenced by the doses of GA3 tested.

Chitarra and Chitarra (2005) suggested that a good quality pineapple fruit should present the SS content between 14 and $16^{\circ}$ Brix. A fruit with the SS content of $12{ }^{\circ}$ Brix is mature (CEAGESP, 2003). Therefore, according to the results obtained, the fruits evaluated fit the standards.

All fruits evaluated in the two seasons (150 and 180 DAIF) showed $\mathrm{pH}$ ranging from 3.30 to 3.83, lower than those found by Pereira et al. (2009) who had verified a range between 4.07 and 4.38. According to Pegoraro et al. (2011), the application of GA3 in peach fruits did not cause any change in fruit quality and increased fruit size. Abu-Zahra \& Salameh (2012) observed that the GA3 application in grape fruits improved fruit quality, as it increased the soluble solids content and reduced the titratable acidity.

\section{CONCLUSION}

The harvesting of pineapple fruits at 180 days after floral induction, together with the application of GA3 45 days before harvesting, provided higher yield, maintaining and improving pineapple 'Pérola' fruit quality.

The use of GA3 does not influence pineapple yield when harvest is performed early, that is, at 150 days after floral induction.

\section{REFERENCES}

ABU-ZAHRA, T.; SALAMEH, N. Influence of Gibberellic Acid and Cane Girdling on Berry Size of Black Magic Grape Cultivar. Middle-East Journal of Scientific Research, v.11, n.6, p. 718-722, 2012.

BENGOZI, J.et al. Qualidades físicas e químicas do abacaxi comercializado na CEAGESP São Paulo. Revista Brasileira de Fruticultura, v. 29, n. 3, p. 540-545, 2007. http://dx.doi.org/10.1590/S010029452007000300025 .

CEAGESP. Centro de Qualidade de Horticultura (CQH)/ Companhia de Entrepostos e Armazéns Gerais de São Paulo. Programa brasileiro para a modernização da horticultura: normas de classificação do abacaxi. São Paulo. Ceagesp, Doc.24, 2003.

CHITARRA, M.; CHITARRA, A. Qualidade pós-colheita de frutos e hortaliças: fisiologia e manuseio. Lavras: ESAL/FAEPE, 2005, 783p.

FAO, 2018. FAOSTAT. Food and Agriculture Organization of the United Nations . Disponível em: http://www.fao.org/faostat/en/\#data/QC Acesso em: 02 abr. 2019.

GIOVANAZ, M. A.et al. gibberellic acid reduces flowering and time of manual thinning in 'maciel' peach trees. Revista Brasileira de Fruticultura, v. 38, n. 2, p. 692. 2016.

https://dx.doi.org/10.1590/0100-29452016692 
IBGE. Instituto Brasileiro de Geografia e Estatística. Levantamento sistemático da produção agrícola 2016. Disponível em: http://www.ibge.gov.br/home/estatistica/indicadores/agropecuaria/lspa/ Acesso em: 07 maio 2016.

KÖPPEN, W. Climatologia: conunestudio de los climas de latierra. Fondo de Cultura Econômica. México, 1948, 479 p.

LI, Y.et al. Exogenous gibberellic acid increases the fruit weight of 'Comte de Paris' pineapple by enlarging flesh cells without negative effects on fruit quality. Acta Physiol. Plant, v. 33, p.1715-1722, 2011. http://dx.doi.org/10.1007/s11738-010-0708-2

MAIA, E.; SIQUEIRA, D.; CECON, P. Produção, florescimento e frutificação de tangerineira 'Poncã' submetida à aplicação de ácido giberélico. Ciência Rural, v. 40, n. 3, p. 507-512, 2010.

http://dx.doi.org/10.1590/S0103-84782010005000025

MODESTO, J.et al. Aplicação de ácido giberélico $\left(\mathrm{GA}_{3}\right)$ em pré-colheita de tangerina 'Poncã' (Citrus reticulata blanco). Acta Scientiarum Agronomy, v. 28, n. 1, p. 37-40, 2006. http://dx.doi.org/ 10.4025/actasciagron.v28i1.1297

PEGORARO, C.et al. Effects of pre-harvest gibberellic acid spraying on gene transcript accumulation during peach fruit development. Plant Growth Regulation, v. 65, n. 2, p. 231-237, 2011.

http://dx.doi.org/10.1007/s10725-011-9591-0

PEREIRA, M.et al. Qualidade do fruto de abacaxi comercializado pela cooperfruto - Miranorte - TO.

Revista Brasileira de Fruticultura, v. 31, n. 4, p. 1048-1053, 2009. http://dx.doi.org/10.1590/S010029452009000400018

PIRES, E.; BOTELHO, R. Emprego de reguladores de crescimento em viticultura. In: Viticultura e Enologia: atualizando conceitos. Belo Horizonte: EPAMIG-FECD, 2002, p. 59-81.

SAHOO A. K.et al. Use of Plant Growth Regulators and Fertilizer for Regulating the Flowering and Quality of Pineapple Fruit - A Review. IJBRITISH, v. 2, n. 1, 2015.

SHARMA, R.; SINGH, R. Gibberellic acid influences the production of malformed and button berries, and fruit yield and quality in strawberry (Fragaria ananassa Duch.). Scientia Horticulturae v. 119, p. 430-433, 2009. http://dx.doi.org/10.1016/j.scienta.2008.11.002

SUKANYA, G.; UTPAL, K; KAUSHIK, D. Effect of GA3 and NAA on reproductive growth and yield development of Assam lemon (Citrus limon L.). Research on Crops. v. 17, v.4, p. 758-762, 2016.

TAIZ, L.; ZEIGER, E. Fisiologia vegetal. 4. ed. Porto Alegre: Artmed, 2009. 722 p.

VIEIRA, C.et al. Reguladores vegetais influenciando número e tamanho de células das bagas da uva 'niagara rosada'. Revista Brasileira de Fruticultura, v. 30, n. 1, p. 25-30, 2008.

http://dx.doi.org/10.1590/S0100-29452008000100007 